China Perspectives

45 | january-february 2003

Varia

\title{
Andrée Feillard ed., L'Islam en Asie, du Caucase à la Chine
}

Paris, La documentation française, 2001, 248 pp.

\section{Rémi Castets}

\section{OpenEdition}

\section{Journals}

Édition électronique

URL : http://journals.openedition.org/chinaperspectives/246

DOI : $10.4000 /$ chinaperspectives. 246

ISSN : 1996-4617

\section{Éditeur}

Centre d'étude français sur la Chine contemporaine

Édition imprimée

Date de publication : 1 février 2003

ISSN : 2070-3449

\section{Référence électronique}

Rémi Castets, «Andrée Feillard ed., L'Islam en Asie, du Caucase à la Chine », China Perspectives [En ligne], 45 I january-february 2003, mis en ligne le 22 août 2006, consulté le 24 septembre 2020. URL http://journals.openedition.org/chinaperspectives/246 ; DOI : https://doi.org/10.4000/ chinaperspectives.246

Ce document a été généré automatiquement le 24 septembre 2020

(c) All rights reserved 


\title{
Andrée Feillard ed., L'Islam en Asie, du Caucase à la Chine
}

Paris, La documentation française, 2001, 248 pp.

\author{
Rémi Castets
}

\section{NOTE DE L'ÉDITEUR}

Translated from the French original by Jonathan Hall

1 This collection sets out to show that Asian Islam is not peripheral, as is often supposed. Relying on their own specialist knowledge, each author gives a general picture of the historical spread of Islam in their particular area: in Russia, the Caucasus, and Central Asia for Stéphane Dudoignon; the Indian subcontinent for Aminah Mohammad-Arif; South-East Asia for Andrée Feillard; and China for Elisabeth Allès. They then analyse the current situation, with particular reference to such topics as the relationship between Islam and politics, religious practices, religious education, or the place of women in Asian Muslim societies.

In considering the contemporary period, Stéphane Dudoignon analyses the complex relations between "official" Islam, "parallel" Islam, mystical orders, and reformist and fundamentalist movements. On the one hand, he emphasises that these aspects, which are sometimes artificially isolated from each other, have come to intermingle in certain cases. On the other hand, he shows that an increasing number of movements are setting themselves up as vectors of alternative socio-political patterns competing with the systems actually in place ${ }^{1}$, and are becoming increasingly radicalised because of their exclusion from political and religious life by the Central Asian regimes. Of course, external influences, particularly the spread of the salafi trend, have aided the expansion of new Islamist movements, especially the radical ones. Nonetheless, despite the growing number of links with the major international Islamist organizations, the writer emphasises (contrary to the belief of a number of Western observers) that the Islamic "revival" to be found in certain societies of the former Soviet Union is the 
outcome of evolutionary developments over a long period of time. Lots of current Islamist movements in this area have their roots in the period of renewal of traditional thinking in the Soviet Union of the 1970s, which had for example a deep impact on the emergence of the Islamic Renaissance Party (p. 57).

In the Indian subcontinent, the shift in status undergone by the Muslim populations, from dominant under the Muslim dynasties to dominated in the colonial period, gave rise to "movements of reaction" (pp. 98-101). Whether they are of the traditional Sufi Islam of the barelwi movement or reformist deobandi, or whether they are modernising or fundamentalist in tendency (Tablighi Jama'at or Jama'at-i-Islami)], all of these movements still play a major role in the political and social life of Pakistan and Bangladesh. Aminah Mohammad-Arif also gives us an analysis of the difficult steps towards improving the situation of women, as well as of the impact of the shortcomings in the religious education system (especially in professional training) in the big three countries of the subcontinent.

4 After laying emphasis on the role of trade, Sufism, and to a lesser extent military conquest (in Indonesia in particular) in the spread of Shafi'i Islam in South-East Asia, Andrée Feillard goes on to study the role of Islam in the nation-building process and the ideology of the different states of the region. She stresses the "problematic" nature of the integration of Muslim communities in the countries where Islam is a minority religion, and she uncovers a certain convergence here with the destiny of the two Islamic "heavyweights" of South-East Asia, namely Indonesia and Malaysia. Although the history of the relations between Islam and politics in these two countries was quite different, whether under colonialism or in the early years of independence, both are now facing a rising tide of Islamism which the governments in power have difficulty in managing.

5 As for China, without passing completely over the Turkic Muslims whose culture and history are more closely related to Central Asia, Elisabeth Allès focuses mainly on the Chinese-speaking Hui nationality, which accounts for nearly nine million out of the total of 17.5 million Muslims in China. The penetration of Islam into China took place via two routes: the first overland through Chinese Turkestan, and the other by sea to the coastal regions of southern China. It was not the outcome of military conquests but of immigration by Muslim merchants and officials (the latter mostly under the Yuan dynasty). The subsequent conversions and intermarriage with the Chinese population allowed the emergence of a homogeneous population, which was to become the Hui nationality in the twentieth century. After examining the rivalries, which were sometimes ferocious, between the Sufi sects, and also between different tendencies (traditional, reformist, ikhwâni, Xidaotang, etc.), the writer analyses the complex relations between the Chinese state and its Muslim subjects, as well as the political process leading to the establishment of the Hui nationality. The "nationality" status of the Hui, the Uighurs, the Kazakhs, etc., became definitively enshrined after the communists took power in 1949. However, since then the Chinese authorities have never ceased to be suspicious about any increase in Muslim claims in the social and political arena. The writer also emphasises the local nature of certain religious practices and the status of women, particularly the existence of women ahong ${ }^{2}$.

6 This volume restores the richness of an Asian Islam hitherto unjustly ignored. Islam became part and parcel of societies which were often quite different from those of the Arab world, a process in which the "opening" of the hanafi school ${ }^{3}$ and the Sufi 
propensity towards syncretism played a determining role. On the other hand, the relations between the historical centres of Islam and Asia very quickly ceased to be a one-way flow, with central Asia and India becoming leading religious centres exercising a widespread and lasting influence over the whole Islamic community. This is all the more reason why, for the last two centuries, the Asian or Eurasian centres of Islam have retained their influence through the spread of models belonging to both the modernising tendency ${ }^{4}$ and the fundamentalist one with its claims to continue the deobandi heritage.

7 Even so, there is a regrettable absence perhaps of any in-depth study of the origin and nature of foreign Islamist influences, whether neo-hanbali, ikhwâni, salafi, or wahhabi. Although these are of external origin, they have provided ideological models for a number of modern radical movements in Afghanistan, the Caucasus, Central Asia, the Indian subcontinent, Indonesia, Malaysia, and the Philippines. Some readers might also be disappointed by the brevity of the analyses of Afghanistan and Kashmir. Despite these few reservations, this clear work of synthesis is to be highly recommended to any reader who wishes to gain a deeper knowledge of Islam today in Asia, and in the heat of current events.

\section{NOTES}

1. These politico-religious movements reject particularly the favouritism and corruption characteristic of the local political systems (see for example the case of the jamâ'at in Daghestan on p. 63, or in Uzbekistan on p. 69).

2. The Chinese for "Imam".

3. According to hanafi teaching, to become a Muslim "it is enough to accept the writings and the messengers from God", a phrasing that allows recent converts to retain a good many of their traditions (p. 25).

4. Like the version spread by the Tatars in Russia in the nineteenth and twentieth centuries. 